\title{
One cell, multiple roles: contribution of mesenchymal stem cells to tumor development in tumor microenvironment
}

\author{
Xue Yang ${ }^{1,2}$, Jing Hou' ${ }^{1}$, Zhipeng Han ${ }^{1}$, Ying Wang ${ }^{2}$, Chong Hao ${ }^{1}$, Lixin Wei ${ }^{1^{*}}$ and Yufang Shi ${ }^{2^{*}}$
}

\begin{abstract}
The discovery of tissue reparative and immunosuppressive abilities of mesenchymal stem cells (MSCs) has drawn more attention to tumor microenvironment and its role in providing the soil for the tumor cell growth. MSCs are recruited to tumor which is referred as the never healing wound and altered by the inflammation environment, thereby helping to construct the tumor microenvironment. The environment orchestrated by MSCs and other factors can be associated with angiogenesis, immunosuppression, inhibition of apoptosis, epithelial-mesenchymal transition (EMT), survival of cancer stem cells, which all contribute to tumor growth and progression. In this review, we will discuss how MSCs are recruited to the tumor microenvironment and what effects they have on tumor progression.
\end{abstract}

Keywords: Mesenchymal stem cells (MSCs), Tumor microenvironment, Tumor growth, Metastasis

\section{Introduction}

Mesenchymal stem cells (MSCs, also called as mesenchymal stromal cells) is a subset of non-hematopoietic adult stem cells which originate from mesoderm. They possess self-renew ability and multilineage differentiation into not only mesoderm-lineage, such as chondrocytes, osteocytes and adipocytes, but also ectodermic cells and endodermic cells [1-5]. MSCs exist in almost all tissues. They can be easily isolated from bone marrow, adipose, umbilical cord, fetal liver, muscle, lung and etc, and can be successfully expanded in vitro [6-10]. Due to lack of specific markers to define MSCs, their identification was depended on the plastic adhesion property, a panel of surface markers, including CD31, CD34, CD45, CD29, CD90, and CD105, as well as multiple differentiation potential. Together with immunosuppressive properties endowed by the inflammation in the damaged tissues, MSCs can display their tissue reparative function. Above

\footnotetext{
*Correspondence: lixinwei@smmu.edu.cn; shiyufang2@gmail.com
'Tumor Immunology and Gene Therapy Center, Eastern Hepatobiliary

* Correspondence: lixinwei@smmu.edu.cn; shiyufang2@gmail.com
${ }^{1}$ Tumor Immunology and Gene Therapy Center, Eastern Hepatobiliary

Surgery Hospital, the Second Military Medicial University, 225 Changhai Road, Shanghai 200438, China

${ }^{2}$ Key Laboratory of Stem Cell Biology, Institute of Health Sciences, Shanghai Jiao Tong University School of Medicine (SJTUSM) \& Shanghai Institutes for Biological Sciences (SIBS), Chinese Academy of Sciences (CAS), Shanghai 200025, China
}

C Biomed Central

(c) 2013 Yang et al.; licensee BioMed Central Ltd. This is an Open Access article distributed under the terms of the Creative Commons Attribution License (http://creativecommons.org/licenses/by/2.0), which permits unrestricted use, distribution, and reproduction in any medium, provided the original work is properly cited. matory diseases, however, with chronic and insufficient inflammation, MSCs cannot rescue the tissue damage, even worsening the disease. Inflammation is always associated with tumor development where tissue suffers from chronic injury. Based on the property of MSCs being recruited to injured tissues, MSCs are used to deliver antitumor reagent directly to tumors for cell based therapy [11-13]. However, the role of MSCs in constructing tumor microenvironment and its potential mechanisms are still controversial. Here, we will focus on the effects of MSCs on the tumorigenesis and tumor metastasis.

The "seed and soil" hypothesis was proposed by Paget in the late nineteenth century, so we can imagine how important the tumor microenvironment is. Tumor microenvironment is very complicated, and includes various cell types, lots of soluble factors, extensive neovasculature [14] and excessive extracellular matrix (ECM) deposition. The network orchestrated by tumor cells, stroma cells [15] and the soluble factors contribute to tumorigenesis, progression, metastases and reoccurrence [16].

MSCs and other components in tumor microenvironment Tumor microenvironment always provides essential conditions to maintain cancer stem cells/cancer initiating 
cells, as well as to boost the cancer cell metastasis. Distinct types of cells, including fibroblast stromal cells (also known as tumor-associated fibroblasts, TAFs) [15,17], immune cells, endothelial cells, adipocytes, and mesenchymal stem cells (MSCs) [17] contribute to tumor progression through crosstalking with each other in either direct or indirect manners. Once tumor develops, TAFs are activated to repair the never healing wound [18]. TAFs play roles in tumor stroma organization by producing plentiful ECM, meanwhile, they contribute to angiogenesis together with endothelial cells and macrophages by producing growth factors, cytokines, chemokines, matrix-degrading enzymes [19]. A growing number of researches demonstrated that blood vessels formed by endothelial cells are responsible for supplying nutrients and transporting metabolic and biological waste [20], thus tumor angiogenesis is important in many types of tumors [21]. In addition, adipocytes, another component of energy supplier, are reported to promote homing, migration and invasion of tumor cells by secreting adipokines including interleukin8 (IL-8) and also make tumors grow rapidly by providing fatty acids [22]. Meanwhile, the immune surveillance built up by tumor-associated macrophage (TAM), NK cells, T cells, B cells, polymorphonuclear leukocytes (PMN), and dendritic cells (DCs) [1] in the tumor sites should not be ignored. They can shift the tumor immune microenvironment, thereby favoring the tumor progression, invasion, malignancy and relapse [17]. With the advent of tissue repair and immune regulatory function of MSCs, MSCs has attracted more attention to their roles in regulating tumor environment $[1,23]$. MSCs are recruited from remote sites into the tumor sites, therein influencing tumor microenvironment by interacting with other cell types or secreting soluble factors. In addition, MSCs are able to differentiate into several stromal cells, such as adipocytes and TAFs [1,7], which was reported in an induced gastric cancer model [24]. Striking evidence also indicated that MSCs played a critical role in tumor vasculogenesis by

Table 1 Cytokines in tumor microenvironment and effects on tumor progression

\begin{tabular}{|c|c|c|c|c|c|}
\hline Cytokines & Cellular sources & Tumor growth & Metastasis & Immune response & References \\
\hline $\mathrm{IL}-1$ & $\begin{array}{l}\text { macrophages, DCs, B cells, NK cells, } \\
\text { keratinocytes, tumor cells }\end{array}$ & + & + & & {$[25,26]$} \\
\hline $\mathrm{IL}-2$ & Th1 lymphocytes & - & & + & {$[26,27]$} \\
\hline $\mathrm{IL}-4$ & Th2 lymphocytes & - & & + & {$[28]$} \\
\hline IL-6 & $\begin{array}{l}\text { T (mainly Th2) and B cells, } \\
\text { keratinocytes and macrophages. } \\
\text { tumor cell, fibroblast, endothelial cells }\end{array}$ & $\begin{array}{l}+ \text { (low concentration) } \\
\text {-(high concentration) }\end{array}$ & & + & {$[25,26,29-31]$} \\
\hline $\mathrm{IL}-8$ & tumor cells & + & & & {$[26]$} \\
\hline$\| \mathrm{L}-10$ & $\begin{array}{l}\text { Th cells, B cells, activated monocytes, } \\
\text { macrophages, thymocytes, } \\
\text { keratinocytes, and tumor cells. }\end{array}$ & + & + & - & {$[29,32,33]$} \\
\hline \multicolumn{6}{|l|}{$\mathrm{IL}-11$} \\
\hline $\mathrm{IL}-12$ & $\begin{array}{l}\text { APC: monocytes, macrophages, and } \\
\text { DCs. tumor cells, neutrophils }\end{array}$ & - & - & + & {$[26,34-38]$} \\
\hline $\mathrm{IL}-15$ & macrophages, DCs & - & & + & {$[39]$} \\
\hline IL-18 & & & - & & {$[26]$} \\
\hline IFN-a & & - & & + & {$[40]$} \\
\hline $\mathrm{IFN}-\beta$ & & - & & + & {$[40]$} \\
\hline $\mathrm{IFN}-\gamma$ & $\begin{array}{l}\text { T (mainly Th1)and B cells, NK cells, NKT } \\
\text { cells, CTL macrophages, mast cells, DCs }\end{array}$ & - & & + & {$[25,26]$} \\
\hline TNF-a & $\begin{array}{l}\text { activated macrophages, T and B cells, } \\
\text { NK cells, tumor cells, neutrophils, } \\
\text { fibroblasts, keratinocytes }\end{array}$ & $\begin{array}{l}\text { +(low concentration) } \\
\text {-(high concentration) }\end{array}$ & & & {$[25,29]$} \\
\hline TGF- $\beta$ & $\begin{array}{l}\text { T and B cells, macrophages, platelets, } \\
\text { bone-marrow stroma, tumor cells }\end{array}$ & - & & + & {$[25,41]$} \\
\hline M-CSF & $\begin{array}{l}\text { macrophages, endothelial cells, } \\
\text { fibroblasts, bone-marrow stroma }\end{array}$ & + & + & & {$[25]$} \\
\hline GM-CSF & $\begin{array}{l}\text { respiratory epithelial cells, T cells, NK } \\
\text { cells, NKT cells, macrophages, } \\
\text { eosinophils, endothelial cells, fibroblasts }\end{array}$ & - & & & {$[25]$} \\
\hline MIF & $\begin{array}{l}\text { macrophages, T cells, eosinophils, } \\
\text { fibroblasts, keratinocytes, pituitary }\end{array}$ & + & & & {$[25]$} \\
\hline
\end{tabular}


differentiating into pericytes and endothelial-like cells [1]. Together with cytokines [Table 1], chemokines [Table 2] and condition where they resided in, MSCs played the indispensable role in regulating different stages of tumor progression.
How MSCs are recruited to tumors?

In normal status, MSCs natively present the tropism of adhering to matrix components, so they prefer to home to bone, lung and cartilage when injected intravenously. Nevertheless, a growing number of studies have shown that

Table 2 Chemokines in tumor microenvironment and effects on tumor progression

\begin{tabular}{|c|c|c|c|c|c|c|}
\hline Chemokines & Chemokine receptors & Cellular sources & Tumor growth & Metastasis & Immune response & References \\
\hline \multirow[t]{2}{*}{ CCL2 } & \multirow[t]{2}{*}{ CCR2 } & \multirow{2}{*}{$\begin{array}{l}\text { tumor cells, macrophages, } \\
\text { endothelial cells, TAFs }\end{array}$} & +(low concentration) & \multirow[t]{2}{*}{+} & \multirow[t]{2}{*}{-} & \multirow[t]{2}{*}[42-46]{} \\
\hline & & & -(high concentration) & & & \\
\hline CCL3 & CCR1,4,5 & endothelial cells & + & + & + & {$[42,47]$} \\
\hline CCL4 & CCR5 & macrophages & + & + & - & {$[42]$} \\
\hline CCL5 & CCR1,3,5 & MSCs, tumor cells, TAFs & + & + & & {$[42,48]$} \\
\hline CCL7 & CCR1,2,3 & & + & + & & {$[42]$} \\
\hline CCL8 & CCR2,3,5 & & + & + & & [42] \\
\hline CCL11 & CCR3 & & + & + & & {$[42]$} \\
\hline CCL12 & CCR2 & & + & + & & {$[42]$} \\
\hline CCL16 & CCR1 & & - & - & & [49] \\
\hline CCL17 & CCR4 & tumor cells, macrophages & - & + & + & {$[42,50]$} \\
\hline CCL18 & unknown & TAM & & + & & {$[42,51]$} \\
\hline CCL19 & CCR7,11 & tumor cells, DCs & - & + & + & {$[42,52]$} \\
\hline CCL20 & CCR6 & tumor cells & - & + & + & {$[53-56]$} \\
\hline CCL21 & CCR7,11 & $\begin{array}{l}\text { lymph nodes, tumor cells, } \\
\text { endothelial cells }\end{array}$ & - & + & & {$[57-64]$} \\
\hline CCL22 & CCR4 & tumor cells, macrophages & - & + & + & {$[42,50,65]$} \\
\hline CCL23 & CCR1 & & + & + & & {$[42]$} \\
\hline CCL24 & CCR3 & & + & + & & {$[42]$} \\
\hline CCL25 & CCR9,11 & & + & + & & [42] \\
\hline CCL26 & CCR3 & & + & + & & {$[42]$} \\
\hline CCL27 & CCR2,3,10 & & + & + & & {$[66]$} \\
\hline CXCL1 & CXCR1,2 & tumor cells, TAFs & + & - & & {$[59,67,68]$} \\
\hline CXCL2 & CXCR2 & tumor cells, TAFs & + & + & & {$[42,67-70]$} \\
\hline CXCL3(GRO- $a, \beta, \gamma)$ & CXCR2 & tumor cells, TAFs & + & - & & {$[67,68,71]$} \\
\hline CXCL5( ENA-78) & CXCR1,2 & & + & + & & {$[42,71,72]$} \\
\hline CXCL6 & CXCR1,2 & & + & + & & {$[42]$} \\
\hline CXCL7(NAP2) & CXCR1,2 & & + & + & & {$[42]$} \\
\hline CXCL8 & CXCR1,2 & $\begin{array}{l}\text { TAFs,endothelial cells, tumor } \\
\text { cells, monocytes }\end{array}$ & + & + & & {$[19,42,59,73-76]$} \\
\hline CXCL9 & CXCR3 & & - & & & {$[77,78]$} \\
\hline CXCL10 & CXCR3 & tumor cells & - & & & {$[59,78]$} \\
\hline CXCL11 & CXCR3 & & - & & & {$[61,79-82]$} \\
\hline CXCL12 & CXCR4 & $\begin{array}{l}\text { tumor cells, astrocytes, } \\
\text { fibroblasts, microglia cells }\end{array}$ & + & + & & {$[61,83-86]$} \\
\hline CXCL13 & CXCR5 & $\begin{array}{l}\text { tumor cells, macrophages, } \\
\text { TAFs }\end{array}$ & + & + & & {$[42,87-89]$} \\
\hline CXCL14 & unknown & & - & & + & [90] \\
\hline CX3CL1 & CX3CR1 & & + & + & & [91-95] \\
\hline PF4 & & & - & & & {$[96,97]$} \\
\hline IP-10 & CXCR3 & & - & & & {$[38,71,80,98]$} \\
\hline MIG & CXCR3 & & - & - & & {$[71,99]$} \\
\hline
\end{tabular}


MSCs home to injury sites induced by inflammation without organ specificity [100-105]. MSCs migration to tumors is due to the tumor microenvironment accompanied by soluble factors produced by inflammaroty and tumor cells and chemokine receptors on MSCs. Those soluble inflammation-associated factors includes growth factors, chemokines and cytokines [17], such as epidermal growth factor (EGF), vascular endothelial growth factor-A (VEGFA), fibroblast growth factor (FGF), platelet-derived growth factor (PDGF), hematopoietic growth factor (HGF), transforming growth factor- $\beta 1$ (TGF- $\beta 1)$, tumor necrosis facror- $\alpha$ (TNF- $\alpha)$ [106-108], stromal cell-derived factor-1 $\alpha$ (SDF-1 $\alpha)$, IL-8, IL-6, granulocyte colonystimulating factor (G-CSF), granulocyte-macrophage colony-stimulating factor (GM-CSF) [101], monocyte chemoattractant protein-1(MCP-1), urokinase-type plasminogen activator (uPA) [109].

Chemokine receptors expressed on MSCs such as CCR1, CCR4, CCR7, CCR9, CCR10, CXCR4, CXCR5, CXCR6, CX3CR1, and c-met lead to their tumor-homing process, too. Recent data implicate the hypoxia status, maintaining the chronic inflammation in tumor, also contribute to MSCs mobilization [110].

Based on the tumor-tropism property of MSCs, they can be used for tumor therapy as delivery vehicles of specific therapeutic genes. Transfering of IFN- $\beta$, IFN- $\gamma$, IL-2, IL-3, IL-12, CCL5, suicide gene cytocine deaminase (CD), adenovirus type 5 early-region 1A (Ad5.E1A) gene, tumor necrosis factor-related apoptosis-inducing ligand (TRAIL) into MSCs have been demonstrated to be anticancer, and transferring of other genes like CX3CL1 and NK4 also can inhibit metastases of tumors [11,111-124]. In addition, gene-enhanced MSCs are more effective for tissue repair and genetic disease treatment than unmodified MSCs [125-133].

\section{MSCs can promote tumor growth}

A lot of functional studies have tackled the question of whether MSCs would influence tumor progression with respect of their tissue reparative function and immunosuppressive properties, however, it is still controversial. In osteosarcoma mouse model, MSCs promoting tumor growth was proved in both in vivo and in vitro study [134]. Similar results were also obtained from cancer cells co-implanted with MSCs in either colon carcinoma [135] or ovarian carcinoma [136]. However, the contrary effect was observed in Kaposi sarcoma (KS) model [135]. The reason for this is the difference in employing different doses of MSCs [137,138]. Nevertheless, MSCs are associated with tumor progression via shifting the balance of tissue microenvironment where they resided. Here, we will discuss their potential mechanisms in regulating tumor development.

\section{MSCs promote angiogenesis in tumor}

Blood Vessels are very important in tumor growth, especially at late stage of tumor progression. Current data suggested that MSCs promoting tumor angiogenesis was mainly dependent on their differentiation potential into endothelial-like cells or pericytes and secreting proangiogenic factors like vascular endothelial growth factor (VEGF), platelet-derived growth factor (PDGF), fibroblast growth factor (FGF) and CXCL12, thereby facilitating angiogenesis [1]. In addition, TAF, a critical component of tumor microenvironment, partly can be derived from MSCs that may be mobilized from local sites or circulation. In immunodeficiency mice, TAFs obtained from human tumor facilitate the growth of human breast and ovarian cancers via inhibiting tumor cell apoptosis, enhancing cell proliferation, as well as promoting angiogenesis [136].

\section{MSCs suppress immune responses}

Extensive investigations have shown that MSCs can exert immunosuppressive function to multiple types of immune cells from either innate immunity or adaptive immunity, such as T cells, B cells, DCs, NK cells and etc. [139]. For T cells, MSCs implemented inhibitory function through secreting high levels of chemokines and inhibitory factor, followed by decreasing $\mathrm{T}$ cell activity locally $[91,140]$. Moreover, MSCs were reported to suppress B cell function via inhibiting chemokine receptors expression [141], to prevent the maturation and cytokine production of DCs and to decrease IL-2 induced proliferation, cytokine production and cytotoxic activity of NK cells. Furthermore, MSCs can promote generation of $\mathrm{T}$ regulatory (Treg) cells $[1,142]$. The factors, such as prostaglandin E2 (PGE2), nitric oxide (NO), indoleamine 2,3-dioxigenase (IDO), PD-L1 and soluble HLA-G5, more or less, are involved in mediating MSCbased suppressive function directly or indirectly [1]. However, it is noteworthy that the immunosuppressive function of MSCs was, not innate, elicited by the synergy effect of interferon- $\gamma$ (IFN $\gamma)$ and any of three other proinflammatory cytokines, TNF $\alpha$, IL-1 $\alpha$, or IL-1 $\beta$ [140].

\section{MSCs inhibit apoptosis of tumor cells}

Recent report has shown that serum-deprived MSCs could facilitate tumor growth and survival by autophagy [143] in both breast cancer animal model and in vitro assay. Tumor progression is accompanied with hypoxia and starvation, because solid tumors with size beyond $2 \mathrm{~mm}$ will limit tumor cells to uptake sufficient nutrient and oxygen due to less vasculature. Under hypoxia and starvation status, MSCs maintain their self-survival via autophagy, meanwhile, they release a lot of anti-apoptotic or pro-survival factors, such as VEGF, bFGF, PDGF, SDF- $1 \alpha$, insulin-like growth factor 1, 2 (IGF-1,2), transforming 
growth factor- $\beta$ (TGF- $\beta$ ) and insulin-like factor binding protein-2 (IGFBP-2) [144-146] to prevent tumor cells from apoptosis and support their proliferation, while normal MSCs do not take this properties. VEGF can increase the Bcl-2/Bax ratio $[147,148]$, bFGF can upregulate Bcl-2 expression [149], PDGF and TGF- $\beta$ can induce the expression of VEGF and bFGF [150]. SDF-1 $\alpha$ was repored to protect chronic lymphocytic leukemia (CLL) cells from apoptosis induced by drug [151]. Nitric oxide (NO), as another important molecule secreted by MSCs, was considered as a bifunctional regulator of apoptosis, proapoptotic at high dose and antiapoptotic at low [152]. Another essential chemokine IL-6 produced by tumor cells and MSCs inhibit apoptosis by upregulating the expression of Bcl-xl [153].

Another perspective also indicated that MSCs are the guardians of tumors, since they can mediate the chemotherapy resistance of tumor cells. Drug resistance was classified into environment mediated-drug resistance (EM-DR), cell adhesion mediated-drug resistance (CAMDR) and soluble factor mediated-drug resistance (SM-DR), the latter two are associated with MSCs [154].

\section{MSCs can promote tumor metastasis}

Metastasis is the major cause of cancer patient death. With more and more potential mechanisms of tumor metastasis are discovered, evidences from in vitro and in vivo studies both pointed out that MSCs have a close relationship with cancer metastasis [155-157]. MSCs induced metastasis only occurs in close proximity to tumor sites while the effect will be reversed when MSCs are inoculated in separate sites, even in nearby sites [156]. Other mechanisms, including epithelial-mesenchymal transition (EMT) induction, regulation of cancer stem cells (CSCs) and mesenchymal niches shifting, are also involved.

\section{MSCs induce EMT of tumor cells}

EMT was first identified as the characteristics of embryogenesis which was described as loss of cell adhesion, repression of E-cadherin expression, and increased cell mobility. The concept of EMT then was extended to tumor metastasis. In breast cancer, when tumor cells were co-cultured with MSCs or MSCs-conditioned medium, tumor cells and MSCs both can be induced to expressed EMT associated molecules [158,159]. Additional researches indicated that EMT appeared to be partly dependent on TGF $\beta$ and VEGF which are associated with MSCs [160,161].

\section{MSCs regulate CSCs proliferation}

Due to CSCs less sensitive to chemotherapy and toxins, they indeed play crucial roles in tumor metastasis [162]. MSCs can enhance CSCs proliferation by secreting cytokines, IL-6 and CXCL7, thereby facilitating the tumor growth [163-165].

\section{MSCs shift mesenchymal niche}

Another mechanism may be pointed to the mesenchymal niche. Growing evidences showed that MSCs can migrate not only to primary tumor sites but also to pre-metastatic sites [166-168]. Factors produced by primary tumors may diffuse to other tissues $[167,168]$ and attract MSCs to be there, which will set up the mesenchymal niche for tumor cell migration. Further researches gave the indication that CCL5 produced by tumor cell-stimulated MSCs, through binding with CCR5, lead the tumor metastasis [156].

\section{Conclusion}

This review draws attention to the complex of MSCs interaction with tumor microenvironment and highlights the fact that both tumor growth and tumor metastasis can be influenced by MSCs directly or indirectly. The effects of MSCs in tumor are varied: the notion that MSCs promoting tumor growth and metastasis has been supported from distinct aspects involved in angiogenesis, tumor cell survival, immunosuppressive microenvironment shape, as well as CSC maintenance and mesenchymal niche construction. However, the controversial results also exist. That can be attributing to the different microenvironment where they reside, the dose employed and their heterogeneity. Therefore, we should pay more attention to MSCbased therapy, especially the potential risk when it works as gene carriers. Nevertheless, it is important to understand the principles and mechanisms of MSCs regulating tumor progression that will give the indication how to employ MSCs to treat tumor.

\section{Abbreviations}

MSCs: Mesenchymal stem cells; TAFs: Tumor-associated fibroblasts; TAM: Tumor-associated macrophage; CSCs: Cancer stem cells; PMN: Polymorphonuclear leukocytes; PGE2: Prostaglandin E2;

IDO: Indoleamine 2,3-dioxigenase; NO: Nitric oxide; TGF- $\beta$ : Transforming growth factor- $\beta$; TNF-a: Tumor necrosis factor- $\alpha$; IFN- $\gamma$ : Interferon- $\gamma$; IL-8: Interleukin-8; IGF-1,2: Insulin-like growth factor-1,2; IGFBP-2: Insulin-like growth factor binding protein-2; VEGF: Vascular endothelial growth factor; FGF: Fibroblast growth factor; PDGF: Platelet-derived growth factor; SDF-1a: Stroma-derived factor-1a; CD: Cytocine deaminase; Ad5.E1A gene: Adenovirus type 5 early-region 1 A gene; TRAlL: Tumor necrosis factorrelated apoptosis-inducing ligand; EGF: Epidermal growth factor; GCSF: Granulocyte colony-stimulating factor; GM-CSF: Granulocyte-macrophage colony-stimulating factor.

\section{Competing interests}

The authors declare that they have no competing interests.

\section{Authors' contributions}

$X Y, J H, Z P H, Y W, C H, L X W$ and YF S planned the manuscript outline. $X Y$ wrote the draft manuscript, J H, ZP H, Y W and $\mathrm{C} H$ revised the manuscript, LX W and YF S finalized the manuscript. All authors read and approve the final manuscript.

\section{Acknowledgements}

This project was supported by Key project of National Natural Science Foundation of China(Grant NO: 81030041); Key Basic Research Project of China (Grant NO: 2010CB945600, 2011CB966200); National Natural Science Foundation of China (Grant NO: 30870974, 30801347, 30901722, 31171321, 81000970, $81101622,30973433,30801094)$; Special Funds for National key Sci-Tech Sepcial Project of China (Grant NO: 2008ZX10002-019, 
2008ZX10002-025); Shanghai Science and Technology Committee (Grant NO: 10ZR1439600, 11ZR1449500, 10411963100, 10ZR1439900,

11 nm0504700,09QA1407200, 07zR14143, 2008B009); Shanghai Municipal Health Bureau(Grant NO: XYQ2011044) and Science Fund for Creative

Research Groups, NSFC, China (Grant NO: 30921006).

Received: 19 October 2012 Accepted: 20 November 2012

Published: 21 January 2013

\section{References}

1. Bianchi G, Borgonovo G, Pistoia V, Raffaghello L: Immunosuppressive cells and tumour microenvironment: focus on mesenchymal stem cells and myeloid derived suppressor cells. Histol Histopathol 2011, 26(7):941-951.

2. Prockop DJ: Marrow stromal cells as stem cells for nonhematopoietic tissues. Science 1997, 276(5309):71-74

3. Granero-Molto F, Weis JA, Longobardi L, Spagnoli A: Role of mesenchymal stem cells in regenerative medicine: application to bone and cartilage repair. Expert Opin Biol Ther 2008, 8(3):255-268

4. Salem HK, Thiemermann C: Mesenchymal stromal cells: current understanding and clinical status. Stem Cells 2010, 28(3):585-596.

5. Dezawa M, Ishikawa H, Itokazu Y, Yoshihara T, Hoshino M, Takeda S, Ide C, Nabeshima Y: Bone marrow stromal cells generate muscle cells and repair muscle degeneration. Science 2005, 309(5732):314-317.

6. Bianco P, Robey PG, Simmons PJ: Mesenchymal stem cells: revisiting history, concepts, and assays. Cell Stem Cell 2008, 2(4):313-319.

7. Pittenger MF, Mackay AM, Beck SC, Jaiswal RK, Douglas R, Mosca JD, Moorman MA, Simonetti DW, Craig S, Marshak DR: Multilineage potential of adult human mesenchymal stem cells. Science 1999, 284(5411):143-147.

8. Anjos-Afonso F, Bonnet D: Nonhematopoietic/endothelial SSEA-1+ cells define the most primitive progenitors in the adult murine bone marrow mesenchymal compartment. Blood 2007, 109(3):1298-1306.

9. Anker PS I't, Scherjon SA, Kleijburg-van der Keur C, de Groot-Swings GM, Claas $\mathrm{FH}$, Fibbe WE, Kanhai HH: Isolation of mesenchymal stem cells of fetal or maternal origin from human placenta. Stem Cells 2004, 22(7):1338-1345.

10. Zuk PA, Zhu M, Mizuno H, Huang J, Futrell JW, Katz AJ, Benhaim P, Lorenz $\mathrm{HP}$, Hedrick MH: Multilineage cells from human adipose tissue: implications for cell-based therapies. Tissue Eng 2001, 7(2):211-228.

11. Studeny M, Marini FC, Champlin RE, Zompetta C, Fidler IJ, Andreeff M: Bone marrow-derived mesenchymal stem cells as vehicles for interferon-beta delivery into tumors. Cancer Res 2002, 62(13):3603-3608.

12. Dvorak HF: Tumors: wounds that do not heal. Similarities between tumor stroma generation and wound healing. N Engl J Med 1986, 315(26):1650-1659.

13. Nakamizo A, Marini F, Amano T, Khan A, Studeny M, Gumin J, Chen J, Hentschel S, Vecil G, Dembinski J, et al: Human bone marrow-derived mesenchymal stem cells in the treatment of gliomas. Cancer Res 2005 65(8):3307-3318.

14. Niess H, Bao Q, Conrad C, Zischek C, Notohamiprodjo M, Schwab F, Schwarz B, Huss R, Jauch KW, Nelson PJ, et al: Selective targeting of genetically engineered mesenchymal stem cells to tumor stroma microenvironments using tissue-specific suicide gene expression suppresses growth of hepatocellular carcinoma. Ann Surg 2011, 254(5):767-774. discussion 774-765

15. Hall B, Dembinski J, Sasser AK, Studeny M, Andreeff M, Marini F: Mesenchymal stem cells in cancer: tumor-associated fibroblasts and cell-based delivery vehicles. Int J Hematol 2007, 86(1):8-16.

16. Hanahan D, Weinberg RA: The hallmarks of cancer. Cell 2000, 100(1):57-70.

17. Korkaya H, Liu S, Wicha MS: Breast cancer stem cells, cytokine networks, and the tumor microenvironment. J Clin Invest 2011, 121(10):3804-3809.

18. Gabbiani G, Majno G: Dupuytren's contracture: fibroblast contraction? An ultrastructural study. Am J Pathol 1972, 66(1):131-146.

19. Silzle T, Randolph GJ, Kreutz M, Kunz-Schughart LA: The fibroblast: sentinel cell and local immune modulator in tumor tissue. Int J Cancer 2004, 108(2):173-180.

20. Philip M, Rowley DA, Schreiber H: Inflammation as a tumor promoter in cancer induction. Semin Cancer Biol 2004, 14(6):433-439.

21. Huh Jl, Calvo A, Stafford J, Cheung M, Kumar R, Philp D, Kleinman HK, Green JE: Inhibition of VEGF receptors significantly impairs mammary cancer growth in C3(1)/Tag transgenic mice through antiangiogenic and non-antiangiogenic mechanisms. Oncogene 2005, 24(5):790-800.
22. Nieman KM, Kenny HA, Penicka CV, Ladanyi A, Buell-Gutbrod R, Zillhardt MR, Romero IL, Carey MS, Mills GB, Hotamisligil GS, et al: Adipocytes promote ovarian cancer metastasis and provide energy for rapid tumor growth. Nat Med 2011, 17:1498-1503.

23. Shi Y, Su J, Roberts Al, Shou P, Rabson AB, Ren G: How mesenchymal stem cells interact with tissue immune responses. Trends Immunol 2012, 33(3):136-143.

24. Quante M, Tu SP, Tomita H, Gonda T, Wang SS, Takashi S, Baik GH, Shibata W, Diprete B, Betz KS, et al: Bone marrow-derived myofibroblasts contribute to the mesenchymal stem cell niche and promote tumor growth. Cancer Cell 2011, 19(2):257-272.

25. Dranoff G: Cytokines in cancer pathogenesis and cancer therapy. Nat Rev Cancer 2004, 4(1):11-22.

26. Nicolini A, Carpi A, Rossi G: Cytokines in breast cancer. Cytokine Growth Factor Rev 2006, 17(5):325-337.

27. Mocellin S, Wang E, Marincola FM: Cytokines and immune response in the tumor microenvironment. J Immunother 2001, 24(5):392-407.

28. Obiri NI, Siegel JP, Varricchio F, Puri RK: Expression of high-affinity IL-4 receptors on human melanoma, ovarian and breast carcinoma cells. Clin Exp Immunol 1994, 95(1):148-155.

29. Salazar-Onfray F, Lopez MN, Mendoza-Naranjo A: Paradoxical effects of cytokines in tumor immune surveillance and tumor immune escape. Cytokine Growth Factor Rev 2007, 18(1-2):171-182.

30. Honma S, Shimodaira K, Shimizu Y, Tsuchiya N, Saito H, Yanaihara T, Okai T: The influence of inflammatory cytokines on estrogen production and cell proliferation in human breast cancer cells. Endocr J 2002, 49(3):371-377.

31. Knupfer H, Schmidt R, Stanitz D, Brauckhoff M, Schonfelder M, Preiss R: CYP2C and IL-6 expression in breast cancer. Breast 2004, 13(1):28-34.

32. Papac RJ: Spontaneous regression of cancer. Cancer Treat Rev 1996, 22(6):395-423.

33. D'Orazio TJ, Niederkorn JY: A novel role for TGF-beta and IL-10 in the induction of immune privilege. J Immunol 1998, 160(5):2089-2098.

34. Vitolo D, Gallo A, Ciocci L, Cicerone E, Baroni CD: Interleukin-12 related cytokine gene expression at a tissue level in carcinomas of the larynx. Eur Arch Otorhinolaryngol 2000, 257(5):290-294.

35. Smyth MJ, Thia KY, Street SE, Cretney E, Trapani JA, Taniguchi M, Kawano T, Pelikan SB, Crowe NY, Godfrey DI: Differential tumor surveillance by natural killer (NK) and NKT cells. J Exp Med 2000, 191(4):661-668.

36. Brunda MJ, Luistro L, Warrier RR, Wright RB, Hubbard BR, Murphy M, Wolf SF, Gately MK: Antitumor and antimetastatic activity of interleukin 12 against murine tumors. J Exp Med 1993, 178(4):1223-1230

37. Nanni P, Rossi I, De Giovanni C, Landuzzi L, Nicoletti G, Stoppacciaro A Parenza M, Colombo MP, Lollini PL: Interleukin 12 gene therapy of MHCnegative murine melanoma metastases. Cancer Res 1998, 58(6):1225-1230.

38. Angiolillo AL, Sgadari C, Taub DD, Liao F, Farber JM, Maheshwari S, Kleinman HK, Reaman GH, Tosato G: Human interferon-inducible protein 10 is a potent inhibitor of angiogenesis in vivo. J Exp Med 1995, 182(1):155-162.

39. Fehniger TA, Suzuki K, Ponnappan A, VanDeusen JB, Cooper MA, Florea SM, Freud AG, Robinson ML, Durbin J, Caligiuri MA: Fatal leukemia in interleukin 15 transgenic mice follows early expansions in natural killer and memory phenotype CD8+ T cells. J Exp Med 2001, 193(2):219-231.

40. Belardelli F, Ferrantini M, Proietti E, Kirkwood JM: Interferon-alpha in tumor immunity and immunotherapy. Cytokine Growth Factor Rev 2002 13(2):119-134

41. Khong HT, Restifo NP: Natural selection of tumor variants in the generation of "tumor escape" phenotypes. Nat Immunol 2002, 3(11):999-1005.

42. O'Hayre M, Salanga CL, Handel TM, Allen SJ: Chemokines and cancer: migration, intracellular signalling and intercellular communication in the microenvironment. Biochem J 2008, 409(3):635-649.

43. Nesbit M, Schaider H, Miller TH, Herlyn M: Low-level monocyte chemoattractant protein-1 stimulation of monocytes leads to tumor formation in nontumorigenic melanoma cells. J Immunol 2001, 166(11):6483-6490

44. Ishida T, Ishii T, Inagaki A, Yano H, Komatsu H, lida $\mathrm{S}$, Inagaki $H$, Ueda R: Specific recruitment of $\mathrm{CC}$ chemokine receptor 4-positive regulatory $\mathrm{T}$ cells in Hodgkin lymphoma fosters immune privilege. Cancer Res 2006 66(11):5716-5722.

45. Jordan JT, Sun W, Hussain SF, DeAngulo G, Prabhu SS, Heimberger AB: Preferential migration of regulatory $T$ cells mediated by glioma-secreted chemokines can be blocked with chemotherapy. Cancer Immunol Immunother 2008, 57(1):123-131. 
46. Mizukami Y, Kono K, Kawaguchi Y, Akaike H, Kamimura K, Sugai H, Fujii H: CCL17 and CCL22 chemokines within tumor microenvironment are related to accumulation of Foxp3+ regulatory T cells in gastric cancer. Int J Cancer 2008, 122(10):2286-2293.

47. Okada N, Gao JQ, Sasaki A, Niwa M, Okada Y, Nakayama T, Yoshie O, Mizuguchi H, Hayakawa T, Fujita T, et al: Anti-tumor activity of chemokine is affected by both kinds of tumors and the activation state of the host's immune system: implications for chemokine-based cancer immunotherapy. Biochem Biophys Res Commun 2004, 317(1):68-76.

48. Zhao M, Mueller BM, DiScipio RG, Schraufstatter IU: Akt plays an important role in breast cancer cell chemotaxis to CXCL12. Breast Cancer Res Treat 2008, 110(2):211-222.

49. Guiducci C, Di Carlo E, Parenza M, Hitt M, Giovarelli M, Musiani P, Colombo MP: Intralesional injection of adenovirus encoding CC chemokine ligand 16 inhibits mammary tumor growth and prevents metastatic-induced death after surgical removal of the treated primary tumor. J Immunol 2004, 172(7):4026-4036.

50. Gough M, Crittenden M, Thanarajasingam U, Sanchez-Perez L, Thompson J Jevremovic D, Vile R: Gene therapy to manipulate effector T cell trafficking to tumors for immunotherapy. J Immunol 2005 174(9):5766-5773.

51. Bonecchi R, Locati M, Mantovani A: Chemokines and cancer: a fatal attraction. Cancer Cell, 19(4):434-435.

52. Braun SE, Chen K, Foster RG, Kim CH, Hromas R, Kaplan MH, Broxmeyer HE, Cornetta K: The CC chemokine CK beta-11/MIP-3 beta/ELC/Exodus 3 mediates tumor rejection of murine breast cancer cells through NK cells. $\mathrm{J}$ Immunol 2000, 164(8):4025-4031.

53. Fushimi T, Kojima A, Moore MA, Crystal RG: Macrophage inflammatory protein 3alpha transgene attracts dendritic cells to established murine tumors and suppresses tumor growth. J Clin Invest 2000, 105(10):1383-1393.

54. Cassier PA, Treilleux I, Bachelot T, Ray-Coquard I, Bendriss-Vermare N, Menetrier-Caux C, Tredan O, Goddard-Leon S, Pin JJ, Mignotte H, et al: Prognostic value of the expression of C-Chemokine Receptor 6 and 7 and their ligands in non-metastatic breast cancer. BMC Cancer, 11:213.

55. Ghadjar P, Coupland SE, Na IK, Noutsias M, Letsch A, Stroux A, Bauer S, Buhr HJ, Thiel E, Scheibenbogen C, et al: Chemokine receptor CCR6 expression level and liver metastases in colorectal cancer. J Clin Oncol 2006, 24(12):1910-1916.

56. Kimsey TF, Campbell AS, Albo D, Wilson M, Wang TN: Co-localization of macrophage inflammatory protein-3alpha (Mip-3alpha) and its receptor, CCR6, promotes pancreatic cancer cell invasion. Cancer J 2004, 10(6):374-380

57. Murooka TT, Wong MM, Rahbar R, Majchrzak-Kita B, Proudfoot AE, Fish EN: CCL5-CCR5-mediated apoptosis in T cells: Requirement for glycosaminoglycan binding and CCL5 aggregation. J Biol Chem 2006, 281(35):25184-25194.

58. Vicari AP, Ait-Yahia S, Chemin K, Mueller A, Zlotnik A, Caux C: Antitumor effects of the mouse chemokine 6 Ckine/SLC through angiostatic and immunological mechanisms. J Immunol 2000, 165(4):1992-2000.

59. Somasundaram R, Herlyn D: Chemokines and the microenvironment in neuroectodermal tumor-host interaction. Semin Cancer Biol 2009, 19(2):92-96

60. Forster R, Davalos-Misslitz AC, Rot A: CCR7 and its ligands: balancing immunity and tolerance. Nat Rev Immunol 2008, 8(5):362-371.

61. Hoelzinger DB, Demuth T, Berens ME: Autocrine factors that sustain glioma invasion and paracrine biology in the brain microenvironment. J Natl Cancer Inst 2007, 99(21):1583-1593.

62. Karnoub AE, Weinberg RA: Chemokine networks and breast cancer metastasis. Breast Dis 2006, 26:75-85.

63. Shields JD, Emmett MS, Dunn DB, Joory KD, Sage LM, Rigby H, Mortimer PS, Orlando A, Levick JR, Bates DO: Chemokine-mediated migration of melanoma cells towards lymphatics--a mechanism contributing to metastasis. Oncogene 2007, 26(21):2997-3005.

64. Strieter RM, Polverini PJ, Kunkel SL, Arenberg DA, Burdick MD, Kasper J, Dzuiba J, Van Damme J, Walz A, Marriott D, et al: The functional role of the ELR motif in CXC chemokine-mediated angiogenesis. J Biol Chem 1995, 270(45):27348-27357.

65. Murakami T, Cardones AR, Finkelstein SE, Restifo NP, Klaunberg BA, Nestle FO, Castillo SS, Dennis PA, Hwang ST: Immune evasion by murine melanoma mediated through CC chemokine receptor-10. J Exp Med 2003, 198(9):1337-1347.
66. Gallagher PG, Bao Y, Prorock A, Zigrino P, Nischt R, Politi V, Mauch C, Dragulev B, Fox JW: Gene expression profiling reveals cross-talk between melanoma and fibroblasts: implications for host-tumor interactions in metastasis. Cancer Res 2005, 65(10):4134-4146.

67. Luan J, Shattuck-Brandt R, Haghnegahdar H, Owen JD, Strieter R, Burdick M, Nirodi C, Beauchamp D, Johnson KN, Richmond A: Mechanism and biological significance of constitutive expression of MGSA/GRO chemokines in malignant melanoma tumor progression. J Leukoc Biol 1997, 62(5):588-597.

68. Balentien E, Mufson BE, Shattuck RL, Derynck R, Richmond A: Effects of MGSA/GRO alpha on melanocyte transformation. Oncogene 1991, 6(7):1115-1124.

69. Owen JD, Strieter R, Burdick M, Haghnegahdar H, Nanney L, Shattuck-Brandt R, Richmond A: Enhanced tumor-forming capacity for immortalized melanocytes expressing melanoma growth stimulatory activity/growthregulated cytokine beta and gamma proteins. Int J Cancer 1997 73(1):94-103.

70. Ruiter D, Bogenrieder T, Elder D, Herlyn M: Melanoma-stroma interactions: structural and functional aspects. Lancet Oncol 2002, 3(1):35-43.

71. Salcedo R, Resau JH, Halverson D, Hudson EA, Dambach M, Powell D, Wasserman K, Oppenheim JJ: Differential expression and responsiveness of chemokine receptors (CXCR1-3) by human microvascular endothelial cells and umbilical vein endothelial cells. FASEB J 2000, 14(13):2055-2064

72. Arenberg DA, Keane MP, DiGiovine B, Kunkel SL, Morris SB, Xue YY, Burdick MD, Glass MC, lannettoni MD, Strieter RM: Epithelial-neutrophil activating peptide (ENA-78) is an important angiogenic factor in non-small cell lung cancer. J Clin Invest 1998, 102(3):465-472.

73. Ramjeesingh $\mathrm{R}$, Leung $\mathrm{R}$, Siu $\mathrm{CH}$ : Interleukin-8 secreted by endothelial cells induces chemotaxis of melanoma cells through the chemokine receptor CXCR1. FASEB J 2003, 17(10):1292-1294.

74. Schadendorf D, Moller A, Algermissen B, Worm M, Sticherling M, Czarnetzk BM: IL-8 produced by human malignant melanoma cells in vitro is an essential autocrine growth factor. J Immunol 1993, 151(5):2667-2675.

75. Schaider H, Oka M, Bogenrieder T, Nesbit M, Satyamoorthy K, Berking C, Matsushima K, Herlyn M: Differential response of primary and metastatic melanomas to neutrophils attracted by IL-8. Int J Cancer 2003, 103(3):335-343.

76. Belperio JA, Keane MP, Arenberg DA, Addison CL, Ehlert JE, Burdick MD, Strieter RM: CXC chemokines in angiogenesis. J Leukoc Biol 2000, 68(1):1-8.

77. Arenberg DA, Kunkel SL, Polverini PJ, Morris SB, Burdick MD, Glass MC, Taub DT, lannettoni MD, Whyte RI, Strieter RM: Interferon-gamma-inducible protein 10 (IP-10) is an angiostatic factor that inhibits human non-small cell lung cancer (NSCLC) tumorigenesis and spontaneous metastases. J Exp Med 1996, 184(3):981-992.

78. Cole KE, Strick CA, Paradis TJ, Ogborne KT, Loetscher M, Gladue RP, Lin W, Boyd JG, Moser B, Wood DE, et al: Interferon-inducible T cell alpha chemoattractant (I-TAC): a novel non-ELR CXC chemokine with potent activity on activated $T$ cells through selective high affinity binding to CXCR3. J Exp Med 1998, 187(12):2009-2021.

79. Liao F, Rabin RL, Yannelli JR, Koniaris LG, Vanguri P, Farber JM: Human Mig chemokine: biochemical and functional characterization. J Exp Med 1995, 182(5):1301-1314.

80. Luster AD, Leder P: IP-10, a -C-X-C- chemokine, elicits a potent thymusdependent antitumor response in vivo. J Exp Med 1993, 178(3):1057-1065.

81. Luster AD, Ravetch JV: Biochemical characterization of a gamma interferon-inducible cytokine (IP-10). J Exp Med 1987, 166(4):1084-1097.

82. Sgadari C, Angiolillo AL, Tosato G: Inhibition of angiogenesis by interleukin-12 is mediated by the interferon-inducible protein 10. Blood 1996, 87(9):3877-3882.

83. Raman D, Baugher PJ, Thu YM, Richmond A: Role of chemokines in tumor growth. Cancer Lett 2007, 256(2):137-165.

84. Barbero S, Bajetto A, Bonavia R, Porcile C, Piccioli P, Pirani P, Ravetti JL, Zona $G$, Spaziante R, Florio T, et al: Expression of the chemokine receptor CXCR4 and its ligand stromal cell-derived factor 1 in human brain tumors and their involvement in glial proliferation in vitro. Ann N Y Acad Sci 2002, 973:60-69.

85. Sehgal A, Keener C, Boynton AL, Warrick J, Murphy GP: CXCR-4, a chemokine receptor, is overexpressed in and required for proliferation of glioblastoma tumor cells. J Surg Oncol 1998, 69(2):99-104.

86. Graeber MB, Scheithauer BW, Kreutzberg GW: Microglia in brain tumors. Glia 2002, 40(2):252-259. 
87. Burkle A, Niedermeier M, Schmitt-Graff A, Wierda WG, Keating MJ, Burger JA: Overexpression of the CXCR5 chemokine receptor, and its ligand, CXCL13 in B-cell chronic lymphocytic leukemia. Blood 2007, 110(9):3316-3325.

88. Lopez-Giral S, Quintana NE, Cabrerizo M, Alfonso-Perez M, Sala-Valdes M, De Soria VG, Fernandez-Ranada JM, Fernandez-Ruiz E, Munoz C: Chemokine receptors that mediate $B$ cell homing to secondary lymphoid tissues are highly expressed in B cell chronic lymphocytic leukemia and nonHodgkin lymphomas with widespread nodular dissemination. J Leukoc Biol 2004, 76(2):462-471.

89. Meijer J, Zeelenberg IS, Sipos B, Roos E: The CXCR5 chemokine receptor is expressed by carcinoma cells and promotes growth of colon carcinoma in the liver. Cancer Res 2006, 66(19):9576-9582.

90. Frederick MJ, Henderson Y, Xu X, Deavers MT, Sahin AA, Wu H, Lewis DE, ElNaggar AK, Clayman GL: In vivo expression of the novel CXC chemokine BRAK in normal and cancerous human tissue. Am J Pathol 2000, 156(6):1937-1950.

91. Lee RH, Pulin AA, Seo MJ, Kota DJ, Ylostalo J, Larson BL, Semprun-Prieto L, Delafontaine P, Prockop DJ: Intravenous hMSCs improve myocardial infarction in mice because cells embolized in lung are activated to secrete the anti-inflammatory protein TSG-6. Cell Stem Cell 2009, 5(1):54-63.

92. Salcedo R, Young HA, Ponce ML, Ward JM, Kleinman HK, Murphy WJ, Oppenheim JJ: Eotaxin (CCL11) induces in vivo angiogenic responses by human CCR3+ endothelial cells. J Immunol 2001, 166(12):7571-7578.

93. Bernardini G, Spinetti G, Ribatti D, Camarda G, Morbidelli L, Ziche M, Santoni A, Capogrossi MC, Napolitano M: 1-309 binds to and activates endothelial cell functions and acts as an angiogenic molecule in vivo. Blood 2000, 96(13):4039-4045

94. Slettenaar $\mathrm{Vl}$, Wilson $\mathrm{J}$ : The chemokine network: a target in cancer biology? Adv Drug Deliv Rev 2006, 58(8):962-974

95. Shulby SA, Dolloff NG, Stearns ME, Meucci O, Fatatis A: CX3CR1-fractalkine expression regulates cellular mechanisms involved in adhesion, migration, and survival of human prostate cancer cells. Cancer Res 2004 64(14):4693-4698

96. Maione TE, Gray GS, Petro J, Hunt AJ, Donner AL, Bauer SI, Carson HF, Sharpe RJ: Inhibition of angiogenesis by recombinant human platelet factor-4 and related peptides. Science 1990, 247(4938):77-79.

97. Sharpe RJ, Byers HR, Scott CF, Bauer SI, Maione TE: Growth inhibition of murine melanoma and human colon carcinoma by recombinant human platelet factor 4. J Natl Cancer Inst 1990, 82(10):848-853.

98. Sgadari C, Angiolillo AL, Cherney BW, Pike SE, Farber JM, Koniaris LG, Vanguri P, Burd PR, Sheikh N, Gupta G, et al: Interferon-inducible protein10 identified as a mediator of tumor necrosis in vivo. Proc Natl Acad Sci USA 1996, 93(24):13791-13796.

99. Addison $\mathrm{CL}$, Arenberg DA, Morris SB, Xue YY, Burdick MD, Mulligan MS, lannettoni MD, Strieter RM: The CXC chemokine, monokine induced by interferon-gamma, inhibits non-small cell lung carcinoma tumor growth and metastasis. Hum Gene Ther 2000, 11(2):247-261

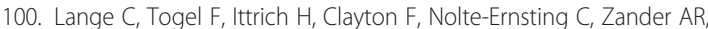
Westenfelder C: Administered mesenchymal stem cells enhance recovery from ischemia/reperfusion-induced acute renal failure in rats. Kidney Int 2005, 68(4):1613-1617

101. Rojas M, Xu J, Woods CR, Mora AL, Spears W, Roman J, Brigham KL: Bone marrow-derived mesenchymal stem cells in repair of the injured lung Am J Respir Cell Mol Biol 2005, 33(2):145-152.

102. Phinney DG, Isakova I: Plasticity and therapeutic potential of mesenchymal stem cells in the nervous system. Curr Pharm Des 2005, 11(10):1255-1265.

103. Sato Y, Araki H, Kato J, Nakamura K, Kawano Y, Kobune M, Sato T, Miyanishi K, Takayama T, Takahashi M, et al: Human mesenchymal stem cells xenografted directly to rat liver are differentiated into human hepatocytes without fusion. Blood 2005, 106(2):756-763.

104. Natsu K, Ochi M, Mochizuki Y, Hachisuka H, Yanada S, Yasunaga Y: Allogeneic bone marrow-derived mesenchymal stromal cells promote the regeneration of injured skeletal muscle without differentiation into myofibers. Tissue Eng 2004, 10(7-8):1093-1112.

105. Silva GV, Litovsky S, Assad JA, Sousa AL, Martin BJ, Vela D, Coulter SC, Lin J, Ober J, Vaughn WK, et al: Mesenchymal stem cells differentiate into an endothelial phenotype, enhance vascular density, and improve heart function in a canine chronic ischemia model. Circulation 2005, 111(2):150-156.

106. Komarova S, Roth J, Alvarez R, Curiel DT, Pereboeva L: Targeting of mesenchymal stem cells to ovarian tumors via an artificial receptor. J Ovarian Res 2010, 3:12.
107. Gao H, Priebe W, Glod J, Banerjee D: Activation of signal transducers and activators of transcription 3 and focal adhesion kinase by stromal cell-derived factor 1 is required for migration of human mesenchymal stem cells in response to tumor cell-conditioned medium. Stem Cells 2009, 27(4):857-865.

108. Djouad F, Plence P, Bony C, Tropel P, Apparailly F, Sany J, Noel D, Jorgensen C: Immunosuppressive effect of mesenchymal stem cells favors tumor growth in allogeneic animals. Blood 2003, 102(10):3837-3844.

109. Honczarenko M, Le Y, Swierkowski M, Ghiran I, Glodek AM, Silberstein LE: Human bone marrow stromal cells express a distinct set of biologically functional chemokine receptors. Stem Cells 2006, 24(4):1030-1041.

110. Spaeth E, Klopp A, Dembinski J, Andreeff M, Marini F: Inflammation and tumor microenvironments: defining the migratory itinerary of mesenchymal stem cells. Gene Ther 2008, 15(10):730-738.

111. Li X, Lu Y, Huang W, Xu H, Chen X, Geng Q, Fan H, Tan Y, Xue G, Jiang X: In vitro effect of adenovirus-mediated human Gamma Interferon gene transfer into human mesenchymal stem cells for chronic myelogenous leukemia. Hematol Oncol 2006, 24(3):151-158.

112. Chen XC, Wang $R$, Zhao X, Wei $Y Q$, Hu M, Wang YS, Zhang XW, Zhang R, Zhang $L$, Yao $B$, et al: Prophylaxis against carcinogenesis in three kinds of unestablished tumor models via IL12-gene-engineered MSCs. Carcinogenesis 2006, 27(12):2434-2441.

113. Kucerova L, Altanerova V, Matuskova M, Tyciakova S, Altaner C: Adipose tissue-derived human mesenchymal stem cells mediated prodrug cancer gene therapy. Cancer Res 2007, 67(13):6304-6313.

114. Xin H, Kanehira M, Mizuguchi H, Hayakawa T, Kikuchi T, Nukiwa T, Saijo Y: Targeted delivery of CX3CL1 to multiple lung tumors by mesenchymal stem cells. Stem Cells 2007, 25(7):1618-1626.

115. Kanehira M, Xin H, Hoshino K, Maemondo M, Mizuguchi H, Hayakawa T, Matsumoto K, Nakamura T, Nukiwa T, Saijo Y: Targeted delivery of NK4 to multiple lung tumors by bone marrow-derived mesenchymal stem cells. Cancer Gene Ther 2007, 14(11):894-903.

116. Stoff-Khalili MA, Rivera AA, Mathis JM, Banerjee NS, Moon AS, Hess A Rocconi RP, Numnum TM, Everts M, Chow LT, et al: Mesenchymal stem cells as a vehicle for targeted delivery of CRAds to lung metastases of breast carcinoma. Breast Cancer Res Treat 2007, 105(2):157-167.

117. Studeny M, Marini FC, Dembinski JL, Zompetta C, Cabreira-Hansen M, Bekele BN, Champlin RE, Andreeff M: Mesenchymal stem cells: potential precursors for tumor stroma and targeted-delivery vehicles for anticancer agents. J Natl Cancer Inst 2004, 96(21):1593-1603.

118. Aboody KS, Najbauer J, Danks MK: Stem and progenitor cell-mediated tumor selective gene therapy. Gene Ther 2008, 15(10):739-752.

119. Nakamura K, Ito Y, Kawano Y, Kurozumi K, Kobune M, Tsuda H, Bizen A, Honmou O, Niitsu Y, Hamada H: Antitumor effect of genetically engineered mesenchymal stem cells in a rat glioma model. Gene Ther 2004, 11(14):1155-1164.

120. Grisendi G, Bussolari R, Cafarelli L, Petak I, Rasini V, Veronesi E, De Santis G, Spano C, Tagliazzucchi M, Barti-Juhasz H, et al: Adipose-derived mesenchymal stem cells as stable source of tumor necrosis factorrelated apoptosis-inducing ligand delivery for cancer therapy. Cancer Res 2010, 70(9):3718-3729.

121. Loebinger MR, Eddaoudi A, Davies D, Janes SM: Mesenchymal stem cell delivery of TRAIL can eliminate metastatic cancer. Cancer Res 2009, 69(10):4134-4142.

122. Menon LG, Kelly K, Yang HW, Kim SK, Black PM, Carroll RS: Human bone marrow-derived mesenchymal stromal cells expressing S-TRAIL as a cellular delivery vehicle for human glioma therapy. Stem Cells 2009, 27(9):2320-2330.

123. Sasportas LS, Kasmieh $R$, Wakimoto $H$, Hingtgen $S$, van de Water JA, Mohapatra G, Figueiredo JL, Martuza RL, Weissleder R, Shah K: Assessment of therapeutic efficacy and fate of engineered human mesenchymal stem cells for cancer therapy. Proc Natl Acad Sci USA 2009, 106(12):4822-4827.

124. Niess H, Bao Q, Conrad C, Zischek C, Notohamiprodjo M, Schwab F, Schwarz B, Huss R, Jauch KW, Nelson PJ, et al: Selective targeting of genetically engineered mesenchymal stem cells to tumor stroma microenvironments using tissue-specific suicide gene expression suppresses growth of hepatocellular carcinoma. Ann Surg 2011, 254(5):767-774. discussion 774-765.

125. Nomura T, Honmou O, Harada K, Houkin K, Hamada H, Kocsis JD: I.V. infusion of brain-derived neurotrophic factor gene-modified human mesenchymal stem cells protects against injury in a cerebral ischemia model in adult rat. Neuroscience 2005, 136(1):161-169. 
126. Kurozumi K, Nakamura K, Tamiya T, Kawano Y, Ishii K, Kobune M, Hirai S, Uchida H, Sasaki K, Ito Y, et al: Mesenchymal stem cells that produce neurotrophic factors reduce ischemic damage in the rat middle cerebral artery occlusion model. Mol Ther 2005, 11(1):96-104

127. Kurozumi K, Nakamura K, Tamiya T, Kawano Y, Kobune M, Hirai S, Uchida H, Sasaki K, Ito Y, Kato K, et al: BDNF gene-modified mesenchymal stem cells promote functional recovery and reduce infarct size in the rat middle cerebral artery occlusion model. Mol Ther 2004, 9(2):189-197.

128. Ishikawa T, Terai S, Urata Y, Marumoto Y, Aoyama K, Sakaida I, Murata T, Nishina $H$, Shinoda K, Uchimura $S$, et al: Fibroblast growth factor 2 facilitates the differentiation of transplanted bone marrow cells into hepatocytes. Cell Tissue Res 2006, 323(2):221-231.

129. Lu Z, Hu X, Zhu C, Wang D, Zheng X, Liu Q: Overexpression of CNTF in Mesenchymal Stem Cells reduces demyelination and induces clinical recovery in experimental autoimmune encephalomyelitis mice. J Neuroimmunol 2009, 206(1-2):58-69.

130. Lu ZQ, Hu XQ, Zhu CS, Zheng XP, Wan DJ, Liu RY, Huang BJ, Huang WL: Bone marrow stromal cells transfected with ciliary neurotrophic factor gene ameliorates the symptoms and inflammation in C57BL/6 mice with experimental allergic encephalomyelitis. Nan Fang Yi Ke Da Xue Xue Bao 2009, 29(12):2355-2361.

131. Zhao MZ, Nonoguchi N, Ikeda N, Watanabe T, Furutama D, Miyazawa D, Funakoshi $H$, Kajimoto $Y$, Nakamura T, Dezawa M, et al: Novel therapeutic strategy for stroke in rats by bone marrow stromal cells and ex vivo HGF gene transfer with HSV-1 vector. J Cereb Blood Flow Metab 2006, 26(9):1176-1188.

132. Aquino JB, Bolontrade MF, Garcia MG, Podhajcer OL, Mazzolini G: Mesenchymal stem cells as therapeutic tools and gene carriers in liver fibrosis and hepatocellular carcinoma. Gene Ther 2010, 17(6):692-708.

133. Doering CB: Retroviral modification of mesenchymal stem cells for gene therapy of hemophilia. Methods Mol Biol 2008, 433:203-212.

134. Xu WT, Bian ZY, Fan QM, Li G, Tang TT: Human mesenchymal stem cells (hMSCs) target osteosarcoma and promote its growth and pulmonary metastasis. Cancer Lett 2009, 281(1):32-41.

135. Zhu W, Xu W, Jiang $R$, Qian $H$, Chen M, Hu J, Cao W, Han C, Chen Y: Mesenchymal stem cells derived from bone marrow favor tumor cell growth in vivo. Exp Mol Pathol 2006, 80(3):267-274.

136. Spaeth EL, Dembinski JL, Sasser AK, Watson K, Klopp A, Hall B, Andreeff M, Marini F: Mesenchymal stem cell transition to tumor-associated fibroblasts contributes to fibrovascular network expansion and tumor progression. PLoS One 2009, 4(4):e4992.

137. Khakoo AY, Pati S, Anderson SA, Reid W, Elshal MF, Rovira II, Nguyen AT, Malide D, Combs CA, Hall G, et al: Human mesenchymal stem cells exert potent antitumorigenic effects in a model of Kaposi's sarcoma. J Exp Med 2006, 203(5):1235-1247.

138. Djouad F, Bony C, Apparailly F, Louis-Plence P, Jorgensen C, Noel D: Earlier onset of syngeneic tumors in the presence of mesenchymal stem cells. Transplantation 2006, 82(8):1060-1066.

139. Han Z, Jing Y, Zhang S, Liu Y, Shi Y, Wei L: The role of immunosuppression of mesenchymal stem cells in tissue repair and tumor growth. Cell Biosci, 2(1):8.

140. Ren G, Zhang L, Zhao X, Xu G, Zhang Y, Roberts Al, Zhao RC, Shi Y: Mesenchymal stem cell-mediated immunosuppression occurs via concerted action of chemokines and nitric oxide. Cell Stem Cell 2008 2(2):141-150.

141. Corcione A, Benvenuto F, Ferretti E, Giunti D, Cappiello V, Cazzanti F, Risso M, Gualandi F, Mancardi GL, Pistoia $V$, et al: Human mesenchymal stem cells modulate B-cell functions. Blood 2006, 107(1):367-372.

142. Patel SA, Dave MA, Murthy RG, Helmy KY, Rameshwar P: Metastatic breast cancer cells in the bone marrow microenvironment: novel insights into oncoprotection. Oncol Rev, 5(2):93-102.

143. Sanchez CG, Penfornis P, Oskowitz AZ, Boonjindasup AG, Cai DZ, Dhule SS, Rowan BG, Kelekar A, Krause DS, Pochampally RR: Activation of autophagy in mesenchymal stem cells provides tumor stromal support. Carcinogenesis, 32(7):964-972.

144. Sanchez C, Oskowitz A, Pochampally RR: Epigenetic reprogramming of IGF1 and leptin genes by serum deprivation in multipotential mesenchymal stromal cells. Stem Cells 2009, 27(2):375-382.

145. Hung SC, Pochampally RR, Hsu SC, Sanchez C, Chen SC, Spees J, Prockop DJ: Short-term exposure of multipotent stromal cells to low oxygen increases their expression of CX3CR1 and CXCR4 and their engraftment in vivo. PLoS One 2007, 2(5):e416.

146. Hung SC, Pochampally RR, Chen SC, Hsu SC, Prockop DJ: Angiogenic effects of human multipotent stromal cell conditioned medium activate the PI3K-Akt pathway in hypoxic endothelial cells to inhibit apoptosis, increase survival, and stimulate angiogenesis. Stem Cells 2007 25(9):2363-2370.

147. Dias S, Choy M, Alitalo K, Rafii S: Vascular endothelial growth factor (VEGF)-C signaling through FLT-4 (VEGFR-3) mediates leukemic cell proliferation, survival, and resistance to chemotherapy. Blood 2002, 99(6):2179-2184.

148. Dias S, Shmelkov SV, Lam G, Rafii S: VEGF(165) promotes survival of leukemic cells by Hsp90-mediated induction of $\mathrm{Bcl}-2$ expression and apoptosis inhibition. Blood 2002, 99(7):2532-2540.

149. Konig A, Menzel T, Lynen S, Wrazel L, Rosen A, Al-Katib A, Raveche E, Gabrilove JL: Basic fibroblast growth factor (bFGF) upregulates the expression of bcl-2 in B cell chronic lymphocytic leukemia cell lines resulting in delaying apoptosis. Leukemia 1997, 11(2):258-265.

150. Brogi $E$, Wu T, Namiki A, Isner JM: Indirect angiogenic cytokines upregulate VEGF and bFGF gene expression in vascular smooth muscle cells, whereas hypoxia upregulates VEGF expression only. Circulation 1994, 90(2):649-652.

151. Burger JA, Tsukada N, Burger M, Zvaifler NJ, Dell'Aquila M, Kipps TJ: Bloodderived nurse-like cells protect chronic lymphocytic leukemia B cells from spontaneous apoptosis through stromal cell-derived factor-1. Blood 2000, 96(8):2655-2663.

152. Stamler JS: Redox signaling: nitrosylation and related target interactions of nitric oxide. Cell 1994, 78(6):931-936.

153. Catlett-Falcone R, Landowski TH, Oshiro MM, Turkson J, Levitzki A, Savino R, Ciliberto G, Moscinski L, Fernandez-Luna JL, Nunez G, et al: Constitutive activation of Stat3 signaling confers resistance to apoptosis in human U266 myeloma cells. Immunity 1999, 10(1):105-115.

154. Li ZW, Dalton WS: Tumor microenvironment and drug resistance in hematologic malignancies. Blood Rev 2006, 20(6):333-342.

155. Tsukamoto S, Honoki K, Fujii H, Tohma Y, Kido A, Mori T, Tsujiuchi T, Tanaka $Y$ : Mesenchymal stem cells promote tumor engraftment and metastatic colonization in rat osteosarcoma model. Int J Oncol, 40(1):163-169.

156. Karnoub AE, Dash AB, Vo AP, Sullivan A, Brooks MW, Bell GW, Richardson AL, Polyak K, Tubo R, Weinberg RA: Mesenchymal stem cells within tumour stroma promote breast cancer metastasis. Nature 2007, 449(7162):557-563.

157. Shinagawa K, Kitadai Y, Tanaka M, Sumida T, Kodama M, Higashi Y, Tanaka S, Yasui W, Chayama K: Mesenchymal stem cells enhance growth and metastasis of colon cancer. Int J Cancer, 127(10):2323-2333.

158. Martin FT, Dwyer RM, Kelly J, Khan S, Murphy JM, Curran C, Miller N, Hennessy E, Dockery P, Barry FP, et al: Potential role of mesenchymal stem cells (MSCS) in the breast tumour microenvironment: stimulation of epithelial to mesenchymal transition (EMT). Breast Cancer Res Treat, 124(2):317-326

159. Yoo YA, Kang MH, Kim BS, Kim JS, Seo JH: Sustained co-cultivation with human placenta-derived MSCs enhances ALK5/Smad3 signaling in human breast epithelial cells, leading to EMT and differentiation. Differentiation 2009, 77(5):450-461.

160. Derynck R, Akhurst RJ, Balmain A: TGF-beta signaling in tumor suppression and cancer progression. Nat Genet 2001, 29(2):117-129.

161. Wanami LS, Chen HY, Peiro S, Garcia de Herreros A, Bachelder RE: Vascular endothelial growth factor-A stimulates Snail expression in breast tumor cells: implications for tumor progression. Exp Cell Res 2008, 314(13):2448-2453.

162. Jing Y, Han Z, Zhang S, Liu Y, Wei L: Epithelial-mesenchymal transition in tumor microenvironment. Cell Biosci 2011, 1:29.

163. Liu S, Ginestier C, Ou SJ, Clouthier SG, Patel SH, Monville F, Korkaya H, Heath A, Dutcher J, Kleer CG, et al: Breast cancer stem cells are regulated by mesenchymal stem cells through cytokine networks. Cancer Res 2011, 71(2):614-624

164. Abarrategi A, Marinas-Pardo L, Mirones I, Rincon E, Garcia-Castro J: Mesenchymal niches of bone marrow in cancer. Clin Transl Oncol 2011 13(9):611-616.

165. McLean K, Gong Y, Choi Y, Deng N, Yang K, Bai S, Cabrera L, Keller E, McCauley L, Cho KR, et al: Human ovarian carcinoma-associated mesenchymal stem cells regulate cancer stem cells and tumorigenesis via altered BMP production. J Clin Invest 2011, 121(8):3206-3219. 
166. Kaplan RN, Riba RD, Zacharoulis S, Bramley AH, Vincent L, Costa C, MacDonald DD, Jin DK, Shido K, Kerns SA, et al: VEGFR1-positive haematopoietic bone marrow progenitors initiate the pre-metastatic niche. Nature 2005, 438(7069):820-827.

167. Bergfeld SA, DeClerck YA: Bone marrow-derived mesenchymal stem cells and the tumor microenvironment. Cancer Metastasis Rev 2010, 29(2):249-261.

168. Chantrain CF, Feron O, Marbaix E, DeClerck YA: Bone marrow

microenvironment and tumor progression. Cancer Microenviron 2008, 1(1):23-35.

doi:10.1186/2045-3701-3-5

Cite this article as: Yang et al:: One cell, multiple roles: contribution of mesenchymal stem cells to tumor development in tumor microenvironment. Cell \& Bioscience 2013 3:5.

\section{Submit your next manuscript to BioMed Central and take full advantage of:}

- Convenient online submission

- Thorough peer review

- No space constraints or color figure charges

- Immediate publication on acceptance

- Inclusion in PubMed, CAS, Scopus and Google Scholar

- Research which is freely available for redistribution 